\title{
Die transformasie van Afrikaans - die afgelope dekade se mediadebat in oënskou
}

\author{
Marlene Verhoef \\ Departement Tale \\ Potchefstroomse Universiteit vir $\mathrm{CHO}$ \\ Vaaldriehoekkampus \\ VANDERBIJLPARK
}

\begin{abstract}
The transformation of Afrikaans - a review of the media debate of the last decade

This article focuses on the language debate concerning the position and status of Afrikaans. This debate has mainly been conducted in Afrikaans newspapers during the past ten years. The apparent trends of the debate are interpreted against the background of transformation as a key concept. Apart from a brief theoretical investigation of the theory of social change, this article explores the applicability of these theoretical parameters on the transformation process to which Afrikaans has been subjected during the last decade.

The article aims to demonstrate that the media debate on Afrikaans which has been conducted by members of the Afrikaans speech community is not unique but illustrates responses typical of all transforming societies regardless of time and space.
\end{abstract}

\section{Navorsingskonteks}

Politieke oorgangsperiodes, soos dié een wat besig is om hom in Suid-Afrika te voltrek, eggo meestal 'n weerklank in die taalpolitiek van 'n spesifieke tydstip (Verhoef, 1996:29). Nie alleen vorm die taalpolitiek as't ware 'n mikrospieëlbeeld van die makro-tendense van sulke veranderingsprosesse nie, maar die transformasie van gemeenskap én taal vind selfs sodanige neerslag in die taalhoudings van die betrokke taalgemeenskappe dat dit ' $n$ wesentlike invloed uitoefen op die totale taalbeplanningscenario van die betrokke taal. Die wese hiervan is dat sosio-politieke transformasie die primêre en sekondêre taalgemeenskappe se houding teenoor die betrokke tale beinnloed. Ook het sodanige transformasie 'n direkte invloed op die status van tale, dit raak die taalkorpus se lewenskragtigheid en dit kom baie duidelik na vore in die uitbreidingsmoontlikhede ten opsigte van die sprekers van só 'n taal. Kortom: dit blyk dan dat grootskaalse sosiale transformasie 'n onafwendbare invloed het op die 
taalkorpus, -status en -bemagtigingsbeplanningsmoontlikhede van alle tale waarvan die spraakgemeenskappe op die een of ander wyse by die veranderingsproses betrokke is.

Voorafgaande waarneming word teoreties begrond deur Cooper (1989:164) se mening dat taalbeplanning in wese ten nouste gemoeid is met enige vorm van sosiale transformasie.

Die doel met hierdie artikel is om die afgelope dekade (1986 tot 1996) as navorsingsperiode af te baken en spesifiek te let in watter mate die politieke veranderingsproses in die daarstelling van 'n nasionale postapartheidsbestel neerslag gevind het in die taalpolitiek van Afrikaans. Die trant van die gesprek oor Afrikaans, soos dit in die openbare mediadebat in Afrikaanse koerante na vore gekom het, vorm die spesifieke navorsingsfokus. Hierdeur word bepaal watter rigting die Afrikaanse gesprek ingeslaan het, in watter mate dit 'n weerspieêling is van die nasionale politieke transformasieproses en watter tendense daaruit af te lei is met betrekking tot die toonaard van die hele gesprek.

Hierdie oorhoofse doelstelling word bereik deur die ontginning van die volgende spesifieke navorsingsdoelwitte:

- Die begrip transformasie word volledig onder die vergrootglas geplaas sodat dit gekontekstualiseer kan word en bepaal kan word watter fases tipies is van sosiale veranderingsprosesse en in watter mate die taalveranderingsproses van die status van Afrikaans tipies is van die makro sosio-politieke transformasieproses in Suid-Afrika.

- Daar word kortliks besin oor die veranderingsfases wat die afgelope tien jaar duidelik geword het ten opsigte van die posisie van Afrikaans en die persepsie van die primêre taalgemeenskap daarteenoor.

- Daar word afgesluit met 'n besinning oor die mate waarin hierdie veranderingsproses van Afrikaans simptomaties is van die nasionale paradigmaverskuiwing in Suid-Afrika.

\section{Transformasie}

\subsection{Begripsomskrywing}

Die begrip transformasie het as't ware reeds 'n modewoordstatus in die vinnig veranderende postapartheid Suid-Afrikaanse samelewing verkry en word in talle situasies, kontekste en vakgebiede gebruik. Hoewel die begrip meestal gebruik word om aan te dui in watter mate besighede, instellings en organisasies hulself op mikrovlak herposisioneer ten opsigte van die sosio-politieke eise van die 
makro Suid-Afrikaanse samelewing, word dit uit die gebruiksfeer van dié woord duidelik dat dit om méér as spontane verandering gaan. In wese dui hierdie begrip op blywende veranderinge wat aan die hand van gestruktureerde opeenvolgende gebeure binne 'n bepaalde tydsverloop voltrek word (Boucher, 1992:9, 28).

Dit blyk verder dat transformasie dui op grootskaalse veranderinge wat ' $n$ invloed uitoefen op die gesamentlike waardes wat gemeenskappe koester, asook op die invloed van sodanige waardeverandering op die gedragstyl van individue binne die veranderende gemeenskappe (Sorokin, 1967:79). Die milieu waarin veranderende gemeenskappe, organismes of samelewingsverbande hulself bevind, oefen ' $n$ bepaalde invloed uit op dié instellings se veranderingsprosesse omdat hierdie groter omringende verbande sélf ook aan verandering onderwerp word (Sorokin, 1967:68). Daar is dus 'n duidelike dinamiese interaktiewe proses aan te toon tussen die mikro-, meso- en makro-entiteite wat by verandering betrokke is.

Sorokin (1967:69) dui ook aan dat die verandering waaraan alle samelewings (in hul totaliteit) onderwerp word, in wese neerkom op die ontginning van sodanige entiteite se eie inherente potensiaal. Dit is ook daarom voor die hand liggend dat geen samelewing of organisme weer na hul oorspronklike vorm kan terugkeer of hulself na die oorspronklike vorm kan verander nie.

Wanneer dit andersyds gaan om die natuurlike kwyning van sosiale sisteme, is dit duidelik dat dit ' $\mathrm{n}$ gevolg is van sodanige gemeenskappe se gebrek aan inherente kreatiwiteit en 'n sterk waardesisteem. Sorokin (1967:79) stel dit duidelik dat, wanneer dit by samelewingsverbande, instellings of organisasies slegs gaan om die bestaan van hul begrensde waardestelsel en dít uitgeput raak, sodanige samelewings neig om hindernisse met 'n remmende invloed op die breë samelewing waarin hulle funksioneer, te wees. Transformasie se wese setel dus as't ware in die bestuur van die ritmiese opeenvolging in die metasisteme wat aanleiding gee tot die inherente kreatiwiteit en lewenskragtigheid van veranderende organismes en samelewingsverbande (Sorokin, 1967:79).

Dit word ook uit die literatuur duidelik dat grootskaalse sosiale verandering op alle vlakke áltyd ' $n$ vasgestelde koers het, al is die doel daarvan nie klinkklaar uitgespel nie (Boucher, 1992:28; Lauer, 1982:4). Daarom is dit belangrik dat die aard, die rigting en die vlak waarop sosiale verandering manifesteer, duidelik verreken word in alle beplanningsfases. 


\subsection{Die reaksie van die veranderende gemeenskappe op transformasieprosesse}

Volgens Lauer (1982:335) veroorsaak die uniekheid van elke situasie dat daar nie werklik 'n universeel-toepasbare strategie geïdentifiseer kan word aan die hand waarvan die bestuur van transformasie beplan kan word nie, maar dat elke situasie 'n veelheid strategieë vra.

Ten spyte van die feit dat dit voorkom of daar nie 'n oorhoofse transformasiestrategie geïdentiseer kan word nie, word dit duidelik gestel dat daar 'n duidelike patroonmatigheid in sosiale veranderingsprosesse te bespeur is. Hierdie patroonmatigheid stel die navorser in staat om sodanige veranderingsprosesse te analiseer, te beskryf en te verstaan (Lauer, 1982:7).

Grootskaalse transformasieprosesse het altyd 'n direkte impak op die veranderende gemeenskap of samelewing wat gewoonlik in verskillende stadiums daarop reageer. Boucher (1992:32) identifiseer 'n reeks opeenvolgende stappe waardeur die reaksie van die veranderende gemeenskap op transformasie oor die algemeen uitgedruk word:

- Aanvanklik is daar ontkenning en gaan die gemeenskap hul gang asof daar geen verandering plaasgevind het nie.

- Dit word gevolg deur weerstand teen verandering en vind plaas wanneer die ontkenningsfase verby is. Hierdie fase word gekenmerk deur gevoelens van twyfel, woede, depressie, angs, frustrasie, vrees en onsekerheid en word gekenmerk deur ' $n$ individuele fokus op die persoonlike impak wat verandering op die lede van die gemeenskap het.

- Die derde fase word gekenmerk deur ondersoek waartydens belangstelhing in die verandering getoon word en daar tekens van verhoogde motivering en kreatiwiteit bestaan ten opsigte van die ingrypende veranderingsprosesse. Daadwerklike pogings word aangewend om op aktiewe wyse deel te hê in die verandering.

- Tydens die laaste fase vind volledige identifisering met die verandering plaas en word visies geformuleer en aksiestappe daargestel om eie gestelde visies te verwesenlik wat in die breë korreleer met die oorhoofse transformasie-agenda.

\subsection{Faktore wat transformasie versnel of kortwiek}

Dit word algemeen aanvaar dat verandering gesien kan word as die reaksie op 'n verskeidenheid faktore wat sodanige verandering aanhelp of teenwerk. Boucher (1992:45 e.v.), Cooper (1989:164-182) en Steyn (1980:54) onderskei 'n aantal 
faktore wat verantwoordelik is vir sosiale transformasieprosesse en vir die tempo waarteen dit plaasvind.

Benewens sekere natuurlike faktore (geografiese, biologiese, demografiese faktore) word tegnologiese faktore (verstedeliking, tegnologiese ontwikkeling, industrialisasie, ekonomie), polities-ideologiese faktore (militêr, polities, ideologies), psigologiese faktore (soos die individuele motiveringsfaktor) en die tydsgees onderskei as determinante wat 'n primêre rol speel in die spoed waarteen transformasie plaasvind.

In teenstelling met die voorafgaande faktore voer Boucher (1992:59 e.v.) aan dat weerstand teen verandering die vernaamste $\mathrm{krag}$ is wat sosiale verandering teenwerk. Dit dui in wese op enige poging wat aangewend word om die bestaande status te handhaaf indien daar bewyse bestaan dat dit besig is om te verander.

By nadere ondersoek word dit duidelik dat die weerstand teen verandering in 'n sikluspatroon verloop: aanvanklik is die weerstand teen verandering heftig wanneer ' $n$ relatief klein persentasie van die instelling, organisasie of struktuur die verandering in ' $n$ ernstige lig beskou. In die tweede stadium, wanneer die verandering veld wen, word die voor- en nadele van die verandering teen mekaar opgeweeg. Die derde stadium word deur konfliksituasies gekenmerk omdat dit duidelik word dat daar ' $n$ onafwendbaarheid in die veranderingspogings bestaan wat reeds op sigbare wyse strukturele vergestalting vind. Vanweë die feit dat die veranderingsagente nie werklike begrip toon vir die teenstanders se onderdrukkingspogings nie, is die konflikpotensiaal groot en speel dit 'n bepalende rol in die voortgang of terminering van die transformasieproses. Indien transformasie voortgaan, word die vierde stadium gekenmerk deur 'n hernieude transformasieimpetus en word dit gekenmerk deur 'n onomkeerbaarheid in die voortgang. Die vyfde stadium vorm in werklikheid weer 'n eerste stadium in die verdere voortgang en word gekenmerk deur ' $n$ weerstand teen voortgaande verandering. (Vergelyk in dié verband Boucher, 1992:60, Bennis et al., 1969:488-489.)

Dit moet egter ook onthou word dat weerstand teen verandering positief beleef kan word omdat dit veranderingsagente tot ' $n$ versigtiger houding dwing en dit meebring dat daar ' $n$ aanpasbaarheid kom in die struktuur van die transformasiepoging in terme van die hele sosiale sisteem waarbinne dit plaasvind (Boucher, 1992:59). Kortom: gebalanseerde weerstand teen verandering bring ' $n$ sigsagpatroon in die transformasieproses mee wat uiteindelik lei tot 'n konsultatiewe veranderingsiklus waardeur maksimale eienaarskap van alle betrokkenes in die proses verseker word. 
Dit word algemeen aanvaar dat die weerstand teen verandering hoog is indien daar, vanwee ' $n$ verskeidenheid faktore, geen behoefte tot verandering bestaan nie en indien daar min individuele openheid daartoe bestaan. Weerstand teen verandering setel gewoonlik in een of meer van die volgende tipes faktore (Boucher, 1992:60-68): kulturele etnosentrisme en die behoud van die bestaande kulturele en sosiale norme- en waardestelsels, 'n gevoel van onsekerheid en regressie, die sug na 'n homeostatiese toestand, die bedreiging van mag en invloed, ' $n$ beperkte verwysingsraamwerk en groepsinsig, tegnologiese struikelblokke en ' $n$ negering van die algemene veranderingsklimaat in die makrosamelewing. Die laaste faktor speel 'n wesentlike rol in enige transformasieproses en die gemeenskap se reaksie daarop, omdat dit die persepsie van individuele lede van die veranderende gemeenskap of samelewingsverband op die verandering tipeer.

\section{Die transformasie van Afrikaans}

\subsection{Inleidend}

Wanneer gekom word by 'n sintese van sosiale veranderingsprosesse en taalveranderingsprosesse word dit duidelik dat daar 'n interafhanklike wedersydse band in die onderskeie prosesse bestaan. Steyn (1980:54) stel dit duidelik dat élkeen van die faktore wat 'n rol speel in sosiale transformasieprosesse 'n wesensrol speel in die groei- of kwynproses van tale se lewenskragtigheid. Cooper (1989:164) se stelling dat sosiale verandering en taalbeplanning eintlik maar net twee kante van dieselfde saak is, onderstreep die onlosmaaklike band tussen taal en samelewing. Om hierdie rede moet die verdiskontering van hierdie sosiale prosesse en aanleidende faktore daartoe 'n baie duidelike neerslag vind in enige taalbeplanningsproses, of die beoordeling daarvan.

Die oorhoofse doel met die res van hierdie artikel is om, teen die agtergrond van die voorafgaande teoretiese verklaring van die wese van transformasieprosesse, antwoorde op die volgende vrae te probeer bied:

- In watter mate het die oorhoofse Suid-Afrikaanse sosio-politieke verandering neerslag gevind in die taalgesprek oor Afrikaans?

- Wat is die toonaard en ondertone van die gesprek?

- In watter mate kan dit verklaar word teen die agtergrond van die gestelde teoretiese beginsels?

- Watter rigtinggewende implikasies kan hierdie bevinding ten opsigte van die toekomstige status van Afrikaans hê? 


\subsection{Metodologie}

Dagbladknipsels wat die afgelope tien jaar (1986 tot 1996) in die Afrikaanse dagbladpers gepubliseer is en wat spesifiek berig gee oor die primêre taalgemeenskap se waarnemings en persepsies in verband met die veranderende posisie van Afrikaans, vorm die navorsingsdata vir die empiriese komponent van hierdie artikel. Die motivering vir hierdie tydsafbakening setel in die feit dat 1986 vir die doeleindes van hierdie navorsing gesien word as 'n gerieflike beginpunt vir die gestruktureerde politieke hervorming in Suid-Afrika (Pampallis, 1991:288). Bakens sedert dié datum op die Suid-Afrikaanse politieke transformasiepad is onder andere 2 Februarie 1990 toe die ontperking van die ANC en die vrylating van mnr. Nelson Mandela aangekondig is; die veelpartysamesprekings van 1991 tot 1993 waarin onderhandel is vir die daarstelling van 'n postapartheidsbedeling in Suid-Afrika; 27 April 1994 toe die eerste algemene verkiesing in die land gehou is; 10 Mei 1994 en die inhuldiging van mnr. Nelson Mandela as die eerste swart president van Suid-Afrika; 1 November 1995 - die landswye plaaslike verkiesings vir die vestiging van 'n veelpartydemokrasie op plaaslike vlak; 10 November 1996 - die halfpadmerk van die huidige regering se bewindstydperk tot met die volgende algemene verkiesing in 1999.

Hierdie grootskaalse nasionale transformasieproses het 'n onafwendbare invloed uitgeoefen op die Afrikaanse spraakgemeenskap se persepsie op dié proses sowel as op die veranderende status van Afrikaans as gevolg van die nasionale sosiopolitieke veranderingsproses.

\subsection{Die tydperk 1986 tot 1989}

Teen die middeltagtigerjare was dit duidelik dat die beleid van afsonderlike ontwikkeling, soos sedert 1948 deur die Nasionale Party gepropageer, nie bevredigende oplossings kon bied vir die komplekse Suid-Afrikaanse werklikheid nie. Sedert 1976 (met die uitbreek van die Soweto-opstand) tot met 1986 het die druk vir hervonningsinisiatiewe al hoe feller geword (Beinart,1994:239; Pampallis, 1991:288; Moorcraft, 1990:361 e.v.). Vanweë die algemene ontnugtering en die toenemende verkenningsgesprekke tussen hervormingsgesinde Suid-Afrikaners en die toe nog verbanne ANC, kan hierdie tydperk beskou word as die eerste fase binne die huidige nasionale transformasieproses.

Hierdie druk om hervorming het in 'n besondere mate neerslag gevind in die taaldebat oor Afrikaans. Die binnegesprek oor Afrikaans is in hierdie tydperk oorheers deur die polarisering tussen die inklusiwiteit en eksklusiwiteit rondom die begrip Afrikaner. Hierdie ideologiese dryfveer het daartoe gelei dat die voorstanders van 'n inklusiewe begrip die tradisionele Afrikaner die sondebok vir die waargenome eksklusiwiteit gemaak het. Dit is opvallend dat daar op hierdie stadium ' $n$ geweldige verdeeldheid in die Afrikaanse taalgemeenskap (en hul 
uitlatings oor Afrikaans) was wat ook tekenend was van die tweespalt in die Afrikanerpolitiek. Enersyds was daar die hervormingsgesindes, soos voorgestaan deur die inisiëring van hervormingspogings deur die Nasionale Party-regering, en andersyds was daar ' $n$ beweging vir die behoud van die beleid van afsonderlike ontwikkeling, soos voorgestaan deur die Konserwatiewe Party wat as eerste regsgesinde opposisie uit die verkiesing in Mei 1987 tree (Moorcraft, 1990:383).

Met betrekking tot die Afrikaanse taalgesprek val die swaar ideologiese lading op Afrikaans op: tydens 'n taalberaad van die destydse Afrikaanse Taalfonds in 1987 in die Paarl sê Piet Muller (toenmalige redakteur van Insig) dat die ideologie van rasse-ongelykheid Afrikaanssprekendes van mekaar geskei het en Afrikaners vreemdelinge in Afrika gemaak het (Die Burger, 10 Oktober 1987). Die beskuldiging dat Afrikaans ideologies swaar belaai is, het die botoon in mediagesprekke gevoer. Hierdie gesprekke gaan primêr om die beskuldiging dat die taal as die eksklusiewe alleenbesit van blanke Afrikaanssprekendes gereken word en dat Afrikaans as onderdrukkerstaal aangewend word om die apartheidsideologie te propageer.

Talle uitsprake uit dié tydperk spreek van die beskuldiging dat Afrikaners self die voortbestaansmoontlikhede van Afrikaans bedreig: In Rapport (11 Oktober 1987) word gesê: "Die eksklusiwiteit van Afrikanerkultuurorganisasies bedreig Afrikaans", "Afrikaans moet losgemaak word van die Afrikaner", "Die wit Boere het Afrikaans te styf aan die hart gedruk en uit skewe liefde hom versmoor". Hierdie idee vind ook neerslag in die volgende aanhalings uit dieselfde tydperk: "Afrikaans is melaats" (Rapport, 6 Maart 1988), "As ons net ons politieke oogklappe wil afhaal, sal ons besef dat Afrikaans in 'n burgeroorlogsituasie is. Dis uiters noodsaaklik dat Afrikaans ontkoppel word van ras en dat die kloof tussen Afrikaanssprekendes oorbrug word" (Die Burger, 22 September 1988) en "Afrikaans het geweldig groot skade gely weens 'n ideologie dat alle gekleurdes minderwaardig en nie in staat tot kultuur is nie" (Die Burger, 22 September 1988). In beriggewing oor dieselfde uitlatings berig Rapport (25 September 1988) dat Afrikaans deur hierdie ideologie meer skade gely het as wat lord Milner ooit kon aanrig.

Dit is duidelik dat daar ' $n$ sekere ongeduldigheid binne 'n bepaalde segment van die Afrikaanse spraakgemeenskap oor die posisie van Afrikaans te bespeur is. Hierdie gevoel stem ooreen met die oënskynlike frustrasie binne die wit Afrikaanse gemeenskap oor die regerende Nasionale Party se trae politieke hervormingspas in Suid-Afrika.

Wynand Malan, 'n voormalige medeleier van die Demokratiese Party, sê in 1989: "Die NP se soort politiek maak dat Afrikaans 'n mindere geleentheid het om 'n rol te speel in die demokratiese stuwing in Suid-Afrika en Afrikaans sal - om in 
eer te kan voortbestaan - die politieke instrument van bevryding moet word" (Die Burger, 11 Mei 1989). Wanneer hierdie uitlating in samehang met die voorafgaande aanhalings gelees word, val dit op in watter mate uitsprake oor die taal gebruik word om die sosiale omgewing te verwoord. Die toonaard van die gesprek in hierdie tydperk spreek nie alleen van 'n verpolariseerde Afrikaanse spraakgemeenskap nie, maar ook van 'n ontnugtering met die hegemoniese situasie waarin Afrikaans ten koste van sy veelrassige spraakgemeenskap gekaap is.

In 'n beoordeling van hierdie eerste transformasiefase op die politieke hervormingspad in Suid-Afrika, en die direkte invloed daarvan op die Afrikaanse spraakgemeenskap, word dit duidelik dat hierdie tydperk duidelike spore toon van die eerste fase van ware transformasie: Hierdie tydperk teken inderdaad die invloed van grootskaalse veranderinge op die gesamentlike waardes van gemeenskappe en die invloed van hierdie waardeverandering op individue binne sodanige veranderende gemeenskappe se gedragstyle. Die feit dat die Afrikaanse gesprek op hierdie stadium hoofsaaklik beperk is tot die sogenaamde intellektueles in die spraakgemeenskap, wys moontlik daarop dat die breë spraakgemeenskap op hierdie stadium nog nie eienaarskap in die proses gehad het nie. Wanneer hierdie verskynsel beoordeel word teen die agtergrond van die fases waarvolgens transformerende gemeenskappe op verandering reageer (kyk Paragraaf 2.2) kom dit voor of hierdie tydperk inderdaad as 'n ontkenningtydperk getipeer kan word. Hierdie aanname word gegrond op die feit dat die grootste segment van die samelewing op onkritiese wyse voortgaan, hoewel die dinamika van die omringende omgewing duidelik spreek van onafwendbare veranderinge.

\subsection{Die tydperk 1990 tot 1994}

Die radikale paradigmaverskuiwing wat 2 Februarie 1990 meegebring het toe die ontperking van die ANC en die vrylating van Nelson Mandela aangekondig is, het meegebring dat die situasie van Afrikaans skielik verander het van taal van die onderdrukker tot taal van die bevryder. Dit is ironies dat die taalgesprek, in die tydperk wat direk op dié ingrypende aankondiging gevolg het, oorheers is deur bespiegelings oor wat die posisie van Afrikaans in só 'n nuwe Suid-Afrikaanse bedeling sou wees.

Hierdie tydperk is op nasionale vlak deur veelparty-onderhandelings gekenmerk en het op sigself heelwat onderbrekings gehad (onder andere die wedersydse wantroue tussen die deelnemende partye, die terminering van Kodesa 1 en 2 en die sluipmoord op mnr. Chris Hani). Tog kan dit op grond van die teoretiese riglyne vir die verloop van transformasieprosesse en gemeenskappe se reaksie daarop (kyk Paragraaf 2.2) as die tweede fase in die breë Suid-Afrikaanse transformasieproses bestempel word. Wanneer noukeurig gelet word op die tipiese 
reaksie van die Afrikaanse spraakgemeenskap op hierdie veranderingsproses en die bespiegeling van die moontlike gevolge daarvan vir Afrikaans, word die volgende duidelik: die spraakgemeenskap se reaksie op die vinnig-veranderende makro-omstandighede en die implikasies daarvan vir Afrikaans, dui inderdaad op die feit dat hierdie tydperk gekenmerk word deur aanvanklike weerstand en verset teen verandering.

Die mening is allerweë gehuldig dat Afrikaans waarskynlik sy amptelike status sal moet prysgee. Insig (Mei 1990) bevat heelwat artikels waarin Afrikaanse akademici en politieke meningsvormers van die regter- en die linkerspektrum hul standpunte weergee. Die politieke kommentator, Dawie (Die Burger, 7 Maart 1990), som die geladenheid van dié debat op deur te sê: "Min dinge wat in die nuwe bedeling wat in Suid-Afrika ontwikkel word, gaan van belangriker simboliese en praktiese betekenis wees as die posisie van Afrikaans".

Hierdie kommentaar volg op reaksie op die algemene gevoel, selfs van binne die Afrikaanse spraakgemeenskap van destyds dat Engels die enigste amptelike taal van 'n nuwe staatkundige bedeling sou wees (Coenie Slabbert in Rapport, 18 Maart 1990; Lina Spies in Die Burger, 11 Augustus 1990; J.C. Steyn in Die Burger, 25 September 1990; Dawie in Beeld, 19 Junie 1993).

Die verskillende bespiegelings oor die toekomsverwagting van Afrikaans dra daartoe by dat ' $n$ baie lewendige debat in die dagbladpers gevoer is en dat die breë primêre spraakgemeenskap op ' $n$ emosionele manier begin deelneem het aan die gesprek. In teenstelling met die feit dat die taalgesprek tot nog toe deur akademici en politici gevoer is, het dit in hierdie tydperk gebeur dat die breë spraakgemeenskap hul menings gewaag het oor die toekomsverwagtinge van Afrikaans in ' $n$ nuwe politieke bedeling. Binne die raamwerk van hierdie artikel onderskryf die opvallende emosionele toonaard van die gesprek die aanname dat weerstand teen verandering in gevoelens van twyfel, angs, frustrasie en onsekerheid manifesteer. Die wese van hierdie onsekerheid setel in die bespiegeling oor die persoonlike impak van die verandering op die taal en lede van die taalgemeenskap (Boucher, 1992:32).

Die omvang van die taaldebat oor die toekomstige status en posisie van Afrikaans in 'n nuwe bedeling het op 'n stadium die koerante só oorheers, dat joernaliste by geleentheid hul verveling daarmee te kenne gegee het en gesê het: "Dit wil lyk of mense nou ' $n$ bietjie uitgekuier raak vir die debat oor die status van Afrikaans in 'n toekomstige bedeling in Suid-Afrika" (Rapport, 16 Augustus 1990). In samehang hiermee tree Afrikaanssprekende akademici en kultuurleiers tot die debat toe en maan dat die openbare debat oor Afrikaans heeltemal te emosioneel en ideologies van aard is en sê dat die voorwaarde 'n rasionele, stylvolle, kalm en bedaarde taalgesprek moet wees waar konsensus oor kernsake nagestreef word 
(Vic Webb, Rapport, 14 Oktober 1990; Henno Cronjé, Beeld 14 Julie 1991; Hendrik Sloet, Rapport, 14 Julie 1991).

Ten spyte van hierdie oproep om kalmte en waardigheid is die mediagesprek oor die toekomstige status van Afrikaans op heftige wyse voortgesit. Die redaksionele kommentaar in Beeld (17 Februarie 1992) lui byvoorbeeld:

Die taalkwessie is een van die plofbaarste vraagstukke in die land. Mense wat die soeke na 'n nuwe politieke bedeling wil misbruik om te torring aan die posisie van Afrikaans as een van die twee amptelike tale, speel met vuur.

Dit is opvallend dat hoe nader die Suid-Afrikaanse samelewing aan die ideaal van ' $n$ nuwe demokratiese bedeling gekom het, hoe dringender het Afrikaanssprekendes hul stemme oor Afrikaans in die dagbladpers laat klink. In 'n brief aan die pers (Beeld, 22 Mei 1993) sê 'n anonieme briefskrywer:

Basta met hierdie druipstert-en-verskonende houding! Wees 'n slag trots op ons taal en op wat Afrikaanssprekendes, ook op die gebied van menseregte, al in hierdie land vermag het. Selfs die ANC se jongste taalbeleid gaan nie so ver as sommige van ons Afrikaanse akademici in hul verguising en miskenning van ons taal nie.

Ook word dit duidelik dat die briewekolomdebatte in hierdie tyd 'n polemiese toonaard vertoon: "Moenie taal as laer vir vrese en agterdog misbruik nie" (Beeld, 17 Junie 1993). In hierdie brief aan die pers waarsku die briefskrywer dat mense wat pleidooie rig vir die behoud van Afrikaans dikwels nie werklik oor die taal begaan is nie, maar dit as rookskerm gebruik om daardeur hul eie bevoorregte posisies te wil beskern. Hiermee word onmiddellik 'n ander dimensie aan die taalgesprek verleen. Nie alleen dui dit op 'n verdeeldheid in die taalgemeenskap oor die intensiteit en toonaard van die mediadebat nie, maar die ideologiese konnotasie van lacrtrek word onmiddellik hierby bereken en die ou verlig/verkramp-onderskeid word weer hierdeur op die spits gedryf. As sodanig lewer hierdie uitlating bewys dat dit in wese gaan om ' $n$ interne spanningsituasie waar die wesentlike impak van die verandering op die individue binne die taalgemeenskap in die sentrum staan.

Die taaldebat het in besondere intensiteit in die tweede helfte van 1993 toegeneem. Dit kan moontlik gewyt word aan sigbare vordering in die grondwetlike veelpartysamesprekings wat gedui het op die onafwendbaarheid van 'n nuwe politieke bedeling en die onsekerheid wat dit vir Afrikaanssprekendes en Afrikaans sou meebring. Daar is selfs deur Piet Muller (assistent-redakteur van Rapport. 31 Oktober 1993) voorspel dat 'n taalstryd voor die deur lê omdat Afrikaans doelbewus gemarginaliseer word. Hierdie uitspraak volg op besluite 
deur die Suid-Afrikaanse Brouerye en Toyota dat Engels voortaan die enigste administrasietaal van hul ondernemings sou wees. Nadat deur kultuurorganisasies gedreig is met boikotaksies het Toyota Suid-Afrika aangekondig dat hul handleidings weer in Afrikaans beskikbaar sal wees en $\mathrm{SAB}$ en Coke het onderneem om weer Afrikaans op die koeldrank- en bierblikkies te gebruik. Beeld (24 Februarie 1993) se redaksionele kommentaar berig:

'n Boikot is 'n uiterste stap wat met groot omsigtigheid benader moet word. Ons hoop nie dit word sommer nodig ter wille van Afrikaans nie. Maar dat Afrikaanssprekendes individueel en gesamentlik moet optree, is gewis. Taaldiplomate, -wagte en selfs -aktiviste sal nodig wees waar 'n tydperk van onsekerheid oor die status van Afrikaans voorlê. Is 'n taalstryd oor 'n blikkie Coke nodig en waardig?

In hierdie tydperk word dit ook duidelik dat die woordkeuse van deelnemers aan die briewekolomme deur strydmetafore oorheers word:

- Kom ons sê vir eens en vir altyd: tot hier en nie verder nie! ... Basta met verskonings vra vir die taal ... Kom ons maak vir 'n verandering ons rûe styf, slaan hakke in die grond en sê baie duidelik en ondubbelsinnig: Tot hier en nie verder nie! (Rapport, 5 Desember 1993).

- Dis tyd dat ons vastrap! (Rapport, 5 Desember 1993).

- Jy kan die ANC nie met Afrikaans of Suid-Afrika vertrou nie. Net so min as wat jy dit aan die Engelse kan oorlaat. Die stryd duur voort! Niks het verander nie (Beeld, 4 Desember 1993).

I.L. de Villiers (in die hoofartikel tot Rapport, 12 Desember 1993) praat van 'n broeiende storm rondom Afrikaans en sê dat die onweerswolke vir Afrikaans in al die raadsale van die land opsteek: bierbrouers, koeldrankvervaardigers, motormaatskappye, staatkundige liggame. Hy sê:

... Want die geskiedenis leer dat 'n taalgemeenskap wat misken word ook 'n politieke storm kan ontketen. En 'n taalgemeenskap wat sy geledere teen verontregting sluit, neem toe in strydlustigheid ... Taalstryde is dikwels die aanjaers van verskeie soorte nasionalismes: van die gematigde, wellewende, maar tog trotse soort tot die militante en selfgeldende tipe.

Die redaksionele kommentaar tot Die Burger (13 Desember 1993) roep sy lesers op en vra: "Veg vir Afrikaans" en in 'n brief aan Die Burger (14 Desember 1993) sê Abraham de Vries: "As daar sprake kan wees van 'n produktebiokot, is dit ook logies om aan politici te sê: praat my taal of jy verloor my stem."

Piet Muller (Rapport, 9 Januarie 1994) praat van 'n taalstryd en sê dat die eintlike stryd van Afrikaans op die Coke- of bierblikkie nie gaan oor Afrikaans 
nie, maar om maatskappye wat politieke guns probeer wen deur weg te staan van Afrikaans. Dit word uit hierdie uitlating duidelik dat die Afrikaanse spraakgemeenskap steeds voel dat Afrikaans gelykgestel word met die politiek van afsonderlike ontwikkeling en as sodanig gee hierdie uitlating aanduiding van die invloed van persepsies van grootskaalse sosio-politieke prosesse op taalsake en die onlosmaaklike invloed van die makro-proses op taalstatus. Hierdie aanname word ook onderskryf in die redaksionele kommentaar tot Rapport (24 Julie 1994): dit word hier duidelik gestel dat die algemene persepsie bestaan dat die emosionele taaldebat wat in 1994 rondom Afrikaans aan die gang was, méér as net die taal behels het. Die emosionele inhoud van woordkeuse het inderwaarheid die somtotaal van 'n sekere lewensuitkyk, kultuur en lewenswyse omvat. En dit is juis in dié opsig dat dit 'n verklaring bied vir die intensiteit waarmee die debat verloop het. Let ter illustrasie op die volgende aanhalings wat 'n aanduiding gee van die emosionele aard van die mediadebat in die periode net vóór en net ná die algemene verkiesing in April 1994:

- FAK se taalstryd met SAUK al hoe feller (Beeld, 22 April 1994).

- 'n Taaloorlog het reeds begin wat in intensiteit sal toeneem na 27 April 1994 (Rapport, 24 April 1994).

- Vir die Afrikanervolk beteken dit die aanbreek van 'n nuwe stryd ... 'n Geweldige stryd, want dit gaan niks anders as 'n geweldige stryd wees om onsself in die nuwe Suid-Afrika ten volle te laat geld nie (Beeld, 14 Mei 1994).

In teenstelling met die emosionele deelname van sekere Afrikaanssprekendes aan die mediagesprek oor Afrikaans, dui Koos Human (redakteur van Insig) aan dat hy iets kleinliks beleef in die Afrikaanse spraakgemeenskap se beheptheid met die aandrang op die gebruik van Afrikaans op bier- en koeldrankblikkies: "Bierblik-Afrikaans: Gesanik hang my by die keel uit" (Beeld, 6 Januarie 1993). In hierdie artikel spreek hy sy misnoeë uit met die oorbeheptheid van Afrikaanssprekendes met die lotgevalle van Afrikaans.

Hierdie idee vind ook neerslag in ' $n$ brief in die briewekolom van Beeld (19 Maart 1994) waarin gesê word dat Afrikaans deur die loop van jare onberekenbare skade berokken is deurdat dit in mense se kele afgedruk is en daar word gewaarsku dat goedbedoelde, dog ondeurdagte optrede ter bevordering van Afrikaans weer eens onberekenbare skade aan die taal kan doen.

In 'n ander brief in die briewekolom sê 'n leser: "Ons raas, stry en dreig met boikotte wanneer ons taal se regte aangetas word. Tog kring die miskenning van Afrikaans net verder uit. Is dit nie dalk deur ons eie toedoen nie?" (Die Burger, 5 Julie 1994). Wanneer hierdie uitlating beoordeel word teen die agtergrond van 
sosiale veranderingsprosesse in die algemeen, word dit duidelik dat hierdie briefskrywer sy/haar frustrasie met die weerstand teen verandering hierdeur uitdruk en in werklikheid waarskynlik wil aandui dat daar 'n onafwendbaarheid in die veranderingsproses is wat aanvaar moet word. Tweedens mag hierdie waarneming daarop dui dat die sterk bewoorde taal waarin die Afrikaanse debat tot nog toe gevoer is, eintlik maar net 'n deel van die spraakgemeenskap se gevoel verwoord en dat die oorgrote swyende meerderheid of die veranderinge aanvaar het, of nooit eienaarskap verkry het in die polemiese sy van die debat nie.

Wanneer die toonaard van die taalgesprek in die tydperk 1990 tot 1994 onder die vergrootglas geplaas word, word dit duidelik in watter mate hierdie taalgesprek 'n barometer is van die politieke transformasie wat hom in Suid-Afrika voltrek het. In teenstelling met 1986/1987 toe die gesprek na binne gerig is en dit gegaan het oor die inklusiwiteit of eksklusiwiteit van die begrip Afrikaner, het dit deur die loop van 1990 tot 1994 gegroei van onsekerheid tot ontnugtering en strydlustigheid. In wese kom dit eintlik daarop neer dat die 1986-1989-fase 'n ontkenningsfase was waarin die eise van grootskaalse sosio-politieke transformasie nog nie in wese tot die breë taalgemeenskap deurgedring het nie. Die tweede fase (1990-1994) waarin die gevoelens van twyfel, woede, vrees en onsekerheid duidelike neerslag in die mediadebat oor Afrikaans gekry het, dui duidelik daarop dat die grense van ontkenning deurbreek is en dat daar op emosionele wyse besin word oor die impak van hierdie makro-proses op Afrikaans. Dit is interessant dat die weerstand teen verandering vanuit die Afrikaanse taalgemeenskap in hierdie tydperk ' $n$ tipiese sikliese patroon vertoon (Boucher, 1992:60, Bennis, et al., 1969:488-489): die eerste en tweede fase in die weerstandsperiode word gekenmerk deurdat 'n klein persentasie van die transformerende samelewing op ernstige wyse besin oor die voorgenome verandering en die voor- en nadele van die verandering teen mekaar opweeg. Toegepas op die Afrikaanssituasie dui dit op die bespiegelinge in 1990 en 1991 binne intellektuele geledere dat Engels waarskynlik die administrasietaal van 'n nuwe Suid-Afrikaanse bedeling sou wees en die akademiese aard van die gesprek oor die toekoms van Afrikaans. Die toetrede van die breë spraakgemeenskap tot die taaldebat en die konflikkarakter van hul deelname tipeer die derde en vierde stadiums binne die weerstandsfase: let byvoorbeeld op die aard van die debat in 1992, 1993 en 1994 wat enersyds gekenmerk is deur heftige deelname deur lede van die breë taalgemeenskap, teenoor die feit dat daar oënskynlik geen begrip van die kant van die veranderingsagente bestaan vir die taalbehoeftes van die Afrikaanse spraakgemeenskap nie. Let in die besonder hier ook op die interne konflik in die beskuldiging vanuit 'n sekere segment in die primêre taalgemeenskap dat daar weer 'n laertreksindroom sigbaar word in die taaldebat. Ondanks dié heftige reaksie van die taalgemeenskap word dit desnieteenstaande 
duidelik dat daar ' $n$ onafwendbaarheid en onomkeerbaarheid in die nasionale transformasieproses aan te toon is.

\subsection{Die tydperk 1995 tot 1996}

'n Nuwe dimensie is tot die Afrikaansdebat gevoeg toe daar teen die einde van 1994 bespiegel is dat die voormalige SAUK se hantering van die taalkwessie verband hou met die afdwing van Engels op die totale Suid-Afrikaanse gemeenskap (Rapport, 11 Desember 1994). Die belangrikheid van hierdie opmerking lê in die feit dat die indruk bestaan dat die Afrikaanse spraakgemeenskap hierdie uitbreiding van Engels as hegemonies en kolonialisties van aard beleef. Dit word ook duidelik dat die onderliggende nasiebou-ideologie (Fishman, 1968, gebruik die begrip nasionisme) wat in die post-apartheidsera in Suid-Afrika duidelik geword het, en waardeur Engels as skakeltaal ten koste van die ander SuidAfrikaanse tale bevorder is, hierdeur op die voorgrond geplaas is. Wanneer die verdere verloop van die taalgesprek in 1995 van naderby bekyk word, word dit duidelik dat hierdie oorkoepelende nasiebougedagte begin veld wen het in die Suid-Afrikaanse gemeenskap.

Hierdie bevordering van 'n breër Suid-Afrikaanse bewussyn as deel van 'n nasiebouprogram het onder andere in 1995 en 1996 meegebring dat Afrikaans toenemend status verloor het, soos uit die volgende feite blyk:

- Die Suid-Afrikaanse Nasionale Weernag besluit on sy tweetalige taalbeleid ten gunste van Engels te laat vaar (Rapport, 29 Januarie 1995; Beeld, 2 Maart 1996, 12 Maart 1996).

- Poste-advertensies van die Departement Handel en Nywerheid vir onder meer die WNNR, SABS, NOK en die Raad op Tariewe en Handel word net in Engelse koerante geplaas (Beeld, 14 Februarie 1995).

- Die SAUK kondig in Februarie 1995 hul "Fast Tracking Program" ten opsigte van televisie-uitsendings aan wat meebring dat Engels as ankertaal meer as $60 \%$ van die sendtyd ontvang en dat Afrikaans se sendtyd drasties verkort word (Rapport, 19 Februarie 1995). Die finale rasionalisering met betrekking tot die taalverdeling by die SAUK (sedert Februarie 1996 South African Broadcasing (Company) word in Februarie 1996 geimplementeer waar Afrikaans se sendtyd tot sowat $3,9 \%$ verkort word (sowat 724 minute per week, teenoor die 2808 minute wat dit vantevore gekry het). Daarteenoor het die sendtyd in Engels toegeneem van 6754 minute per week tot 11051 na die herstrukturering (Beeld, 2 Februarie 1996).

- Gerugte ontstaan dat enkeltalige Afrikaansmediumskole en -universiteite gedwing sal word om 'n dubbelmediumvoertaalbeleid te implementeer anders 
sal hul staatsubsidie opgeskort word (Rapport, 29 Januarie 1995, 11 Februarie 1995, Beeld, 30 Januarie 1996). Trouens, die finalisering van die finale grondwet het in April 1996 juis amper tot 'n stilstand gekom omdat geen ooreenkoms aanvanklik bereik kon word oor die verskansing van moedertaalonderrig in die grondwet nie (Naweek-Beeld, 27 April 1996).

- Yskor besluit om sy naam na Iscor te verander en kondig, net soos die Kinderen Gesinsorgvereniging, aan dat dit te duur is om dokumentasie in Afrikaans en Engels op te stel en besluit op Engels as dié organisasies se werkstaal (kyk o.a. Beeld, 27 Junie 1995, 1 Desember 1995, 30 Desember 1995).

- Die Suid-Afrikaanse Lugdiens kondig in Oktober 1996 aan dat daar afgesien word van die gebruik om afkondigings op binnelandse vlugte in vier tale te doen en besluit op Engels as die enigste kommunikasiemedium vir alle vlugafkondigings (Beeld, 31 Oktober 1996).

Ten spyte van 'n oënskynlik uitsiglose toekomsverwagtinge wat die spesifieke status van Afrikaans betref, is dit opvallend dat daar 'n bewustheid kom vir 'n meertalige taalbedeling in Suid-Afrika: Langtag (Language Task Group) wat deur die Minister van Kuns, Kultuur, Wetenskap en Tegnologie in die lewe geroep is, veroordeel die tendens tot die hegemonie van Engels in die SuidAfrikaanse samelewing (Rapport, 30 Junie 1996; Beeld, 9 Augustus 1996). Daarbenewens kondig die Nasionale Kommissie vir Hoër Onderwys in hul gespreksraamwerk aan dat, hoewel Engels die geskikste werkstaal op tersiêre onderwysvlak is, die opheffing van Afrikatale as wetenskapstale spesifieke aandag moet kry (Beeld, 11 Oktober 1996).

Ten opsigte van die mediagesprek oor Afrikaans is dit opvallend dat dit in 1995 en 1996 nie werklik meer deur emosionele taalgebruik en strydmetafore gevoer word nie, behalwe in gevalle waar die Afrikaanse taalgemeenskap reageer op die SAUK/SABC se hantering van Afrikaans (kyk onder andere Beeld, 19 Januarie 1995, 21 Februarie 1995, 1 Maart 1995, 30 Augustus 1995, 7 September 1995, 8 Februarie 1996, 14 Februarie 1996, 16 Februarie 1996).

Hoewel dit wel gedurende 1995 en 1996 gebeur het dat die spraakgemeenskap hul misnoeë uitspreek oor die hantering van Afrikaans op makrovlak, is dit opvallend dat 'n klemverskuiwing ten opsigte van die toonaard van die gesprek intree. Oor die algemeen word die Afrikaanse spraakgemeenskap opgeroep on betrokke te raak in die gesamentlike ontwikkeling van 'n nuwe omvattende SuidAfrikaanse samelewing (Beeld, 10 Januarie 1995, 23, 24, 25, 26 Januarie 1996). In samehang hiermee word berig gegee van mnr. Mandela se versoeningspolitiek en die toenadering wat hy met Afrikaanssprekendes soek (Beeld, 22 Februarie 1995, 23 Februarie 1995, 29 April 1995, Rapport, 24 September 1995, 14 
Januarie 1996, 9 Februarie 1996). Ten spyte van hierdie versoeningsgebare teenoor Afrikaanssprekendes word die President se waarskuwing aan Afrikaanssprekendes dat hulle op aktiewe wyse betrokke móét raak by 'n groter SuidAfrikaanse bewussyn en hulself nie in rasseterme moet sien nie, ook berig (Rapport, 14 Januarie 1996, Beeld, 15 Januarie 1996).

Dit is opvallend dat daar vanuit die primêre spraakgemeenskap spesifiek berig word oor 'n interne bewusmakingsproses waar onder andere gevra word vir onderlinge samewerking tussen Afrikaanssprekendes sodat 'n gesamentlike visie in die veranderende sosio-politieke konteks geskep kan word (Beeld, 10 Januarie 1995, 18 September 1995, 23, 24, 25, 26 Januarie 1996, 15 November 1996, Rapport, 11 Februarie 1995, 12 Maart 1995, 19 Maart 1995, 24 September 1995, 1 Oktober 1995, 17 November 1996). Die oproep word gedoen dat hierdie gesamentlike soeke na 'n visie moet geskied ten spyte van verskillende politieke affiliasies.

By 'n besinning oor die verloop van die mediagesprek in 1995 en 1996 val dit op dat daar 'n klemverskuiwing ingetree het. Dit kom voor of die oënskynlike gebrek aan belangstelling en die afwesigheid van massa-deelname aan die briefkolomdebatte in hierdie tydperk in wese dui op die manifestering van die derde en vierde fases ten opsigte van die transformerende gemeenskappe se reaksie op verandering. Fase drie gaan om 'n verhoogde belangstelling en kreatiwiteit ten opsigte van die bestaande veranderingsprosesse en die rol wat daarin vertolk kan word. In fase vier gaan dit om 'n identifisering met die verandering en die formulering van ' $n$ eie visie wat die herposisionering binne die makro veranderende omstandighede.

Hierdie aanname word ondersteun wanneer noukeurig gelet word op die tekens van pro-aktiewe optrede vanuit die Afrikaanse gemeenskap ten einde 'n herposisionering binne die nuwe politieke bestel te bewerkstellig: let byvoorbeeld op die toenemende oproepe om onderlinge samewerking tussen Afrikaanssprekendes sodat ' $n$ gesamentlike visie binne die veranderende politieke konteks bewerk kan word. Dit kom selfs voor asof die vierde fase ten opsigte van die transformerende gemeenskap se reaksie op verandering, naamlik 'n identifisering met die verandering, al hoe duideliker word binne die Afrikaanse gemeenskap: in mediaberigte in Oktober en November 1996 word berig van verkenningsgesprekke tot die daarstelling van 'n sambreelorganisasie wat op bopolitiese wyse wil fokus op die Afrikaanse taalbelange en as katalisator vir alle Afrikaanssprekendes wil optree (Beeld, 15 November 1996, Rapport, 17 November 1996). Hierdie fonnulering van 'n nuwe visie en die daarstel van sekere aksiestappe gee 'n aanduiding daarvan dat daar spore bestaan van volledige identifisering met die makro sosio-politieke veranderinge. 


\section{4. 'n Besinning oor die waargenome tendense in die Afrikaanse taaldebat}

Dit word uit die afgelope tien jaar se mediagesprek oor Afrikaans duidelik dat die gesprek, soos nog altyd, 'n groter sosio-politieke werklikheid geëggo het en daarom nog nooit werklik van ideologiese geladenheid kon wegkom nie. Dit is in die besonder duidelik dat die primêre spraakgemeenskap se persepsies van die status van Afrikaans in hierdie tydperk tiperend is van die wyse waarop hulle die veranderende sosio-politieke omgewing geïnterpreteer het.

Hoewel Lauer (1982:6) dit duidelik stel dat veranderinge op een samelewingsvlak nie noodwendig verbind kan word met sosiale veranderinge op ander vlakke nie, blyk dit uit die vergelyking tussen die afgelope tien jaar se mediagesprek oor Afrikaans en die nasionale politieke transformasieproses in Suid-Afrika dat daar 'n aantoonbare korrelasie tussen die twee prosesse bestaan. Die opvallendste ooreenkoms is aan te toon in die transformerende Afrikaanse gemeenskap se reaksie op die oorhoofse transformasieproses en die invloed en toekomsimplikasies daarvan op Afrikaans.

Dit blyk in die besonder dat die reaksie van die primêre Afrikaanse gemeenskap soos dit in die Afrikaanse media weerspieel word (óf by wyse van direkte deelname aan die briewekolomme, of by wyse van rapportering) 'n duidelike aanduiding gee van die tipiese reaksie van transformerende gemeenskappe op veranderingsprosesse. Dit is interessant dat daar in in die afgelope tien jaar se Afrikaansdebat in werklikheid sprake is van die volle spektrum reaksies wat ontwikkel het van ontkenning, angs, frustrasie, woede en ontnugtering tot by die opweeg van die voor- en nadele van die verandering en die pro-aktiewe maak van planne wat ' $n$ bydrae te midde van verandering sal verseker.

In 'n besinning oor die faktore wat inwerk op die nasionale transformasie in SuidAfrika se invloed op die veranderende status van Afrikaans en die persepsies van die Afrikaanse gemeenskap, is dit duidelik dat polities-ideologiese en psigologiese faktore wat in die heersende tydsgees weerspieël word, ' $n$ bepalende rol in hierdie verband gespeel het.

Ten opsigte van die implikasies van hierdie transformasiesiklus op die toekoms van Afrikaans te midde van 'n breë veranderende samelewing, word dit duidelik dat daar van 'n paradigmaverskuiwing sprake is wat dui op 'n verandering ten opsigte van die tyds- en sosio-politieke kader. Hierdie nuwe paradigma se vérreikende gevolge op die status en posisie van Afrikaans het nie alleen duidelik geword uit die afgelope tien jaar se mediagesprek nie, maar sal sekerlik ook, wat die onmiddellike toekoms van Afrikaans betref, verreken móét word. 


\section{Bibliografie}

Beinart, W. 1994. Twentieth-century South Africa. Oxford : Oxford Unversity Press.

Bennis, W.G. et al. 1969. The planning of change. New York: Holt, Rinehart \& Winston.

Boucher, H. 1992. Die Suid-Afrikaanse samelewing in transformasie: enkele implikasies vir die onderwys en opvoedkunde. Port Elizabeth : UPE. (M.Ed -verhandeling.)

Cooper, R.L. 1989. Language plaming and social change. Cambridge : Cambridge University Press.

Fishman, J.A. 1968. Nationality-nationalism and nation-nationism. In: Fishman, J.A. Ferguson, C.A. \& Das Gupta, J. (eds.) Language problems of developing nations. New York : John Wiley. p. 39-51.

Lauer, R.H 1982. Perspectives on social change. Boston : Allyn \& Bacon.

Moorcraft, P.L. 1990. African nemesis: war and revolution in Southern Africa (1945-2010). London : Brassey's (UK).

Pampallis, J. 1991. Foundations of the new South Africa. Cape Town : Maskew Miller.

Sorokin, P.A. 1967. Reasons for sociocultural change and variably recurrent processes In: Moore, W E. \& Cook, R.M. (eds.) Readings on social change. Englewood Cliffs: Prentice Hall. p. 68-80.

Steyn, J.C. 1980. Tuiste in eie taal. Kaapstad : Tafelberg.

Verhoef, M. 1996. Politieke determinante in die hedendaagse gesprek oor Afrikaans. Literator, 17(3):29-44, November. 
